\title{
A Review of 2,4-D Environmental Fate, Persistence and Toxicity Effects on Living Organisms
}

\author{
Chali Abate Jote* \\ Department of Chemistry, Nekemte College of Teacher Education, Nekemte, Ethiopia
}

Submission: October 28, 2019; Published: November 13, 2019

"Corresponding author: Chali Abate Jote, Department of Chemistry, Nekemte College of Teacher Education, P 0 B 88, Nekemte, Ethiopia

Abstract

2,4-D is one of the most used herbicides in the world. It has been used since 1940s and its popularity seems to be increasing. Due to its broad range of application and excessive usage, it has becoming a serious problem as it can cause pollution to the environment. Extensive researches have been done for 2,4-D but comparatively few for its derivatives. Therefore, in this review article, I focused on 2,4-D environmental fates, persistence and effects on living organisms. Hence, its toxicity levels, toxicity classification and ecotoxicity studies were reviewed based on available references. In this review article, also discussed the toxicity effects of 2,4-D on animals and humans.

Keywords: 2,4-D; Herbicides; Environmental fate; Persistence; Toxicity; Effects; Animals; Humans

\section{Introduction}

2,4-D is one of the oldest herbicides used in the United States. It was first developed during World War II and became famous as a component of the controversial Agent Orange used during the Vietnam War [1]. Today, 2,4-D continues to be one of the most commonly used herbicides on the market. Because there is no longer a patent governing the manufacture and sale of 2,4-D, any company is free to produce it. Thus, a variety of inexpensive 2,4-D products are available from different manufacturers. Because it has been in use for so long, many of the studies regarding its behavior in the environment are old [2]. 2,4-D is a selective herbicide that kills dicots (but not grasses) by mimicking the growth hormone auxin, which causes uncontrolled growth and eventually death in susceptible plants $[3,4]$. The half-life of 2,4-D in the environment is relatively short, averaging 10 days in soils and less than 10 days in water, but can be significantly longer in cold, dry soils, or where the appropriate microbial community is not present to facilitate degradation [5].

In the environment, most formulations are degraded to the anionic form, which is water-soluble and has the potential to be highly mobile. Ester formulations are toxic to fish and aquatic invertebrates, but salt formulations are registered for use against aquatic weeds [4]. 2,4-D is of relatively low toxicity to animals, but some formulations can cause severe eye damage. Certain crops, such as grapes, are highly sensitive to 2,4-D and application of this herbicide should be avoided if they are nearby [5]. Most formulations are highly volatile and should not be applied when conditions are windy or when temperatures are high [6].

\section{Historical Perspectives}

2,4-D is commonly known as a component of the controversial herbicide Agent Orange, which was extensively used by the U.K. in Malaysia and by the U.S. military during the Vietnam War to defoliate jungle regions [6]. Agent Orange's infamy was primarily due to dioxin contamination of the 2,4-D and 2,4,5-T herbicides that it contained. 2,4-D is now manufactured with a process that produces no dioxin as a contaminant. It proved impossible to produce 2,4,5-T that was free of dioxin contamination, so its manufacture and sale have been prohibited in the U.S. since 1983. Small quantities of this dioxin are highly toxic and have been linked with producing birth defects in mammals and increased rates of cancer [7].

\section{Mode of Action}

2,4-D is an "auxin mimic" or synthetic auxin. This type of herbicide kills the target weed by mimicking the plant growth hormone auxin (indole acetic acid), and when administered at effective doses, causes uncontrolled and disorganized plant growth that leads to plant death. The exact mode of action of 2,4-D is not fully understood, and it is possible that it causes a variety of effects which are fatal when combined [1]. It is believed to acidify the cell walls which allow the cells to elongate in an uncontrolled manner. Low concentrations of 2,4-D can also stimulate RNA, DNA, and protein synthesis leading to uncontrolled cell division and growth, and, ultimately, vascular tissue destruction [2]. On the other hand, high concentrations of 2,4-D can inhibit cell division 
and growth. Plant death typically occurs within three to five weeks following application [5].

\section{Physico-Chemical Properties}

Table 1: Physical/chemical properties of 2,4-D, Adapted from: $[5,11-$ 14].

\begin{tabular}{|c|c|}
\hline Characteristics & Values (Results) \\
\hline Molecular weight & $221.04 \mathrm{~g} / \mathrm{mol}$ \\
\hline Melting point & $135-142^{\circ} \mathrm{C}$ \\
\hline Boiling point (at $0.4 \mathrm{mmHg})$ & $160^{\circ} \mathrm{C}$ \\
\hline Water solubility $\left(\right.$ at $\left.25^{\circ} \mathrm{C}\right)$ & $3.39 \times 10^{4} \mathrm{ppm}$ \\
\hline Vapor pressure $\left(\right.$ at $\left.25^{\circ} \mathrm{C}\right)$ & $1.4 \times 10^{-7} \mathrm{mmHg}$ \\
\hline Hydrolysis half-life $\left(\right.$ at $25^{\circ} \mathrm{C} \& \mathrm{pH}=7$ ) & 39 days \\
\hline Aqueous photolysis half-life $\left(\right.$ at $\left.25^{\circ} \mathrm{C}\right)$ & 13 days \\
\hline Anaerobic aquatic half-life & 312 days \\
\hline Aqueous aerobic half-life & 15 days \\
\hline Aerobic half-life & 66 days \\
\hline Soil photolysis half-life & 393 days \\
\hline Field dissipation half-life & 59.5 days \\
\hline Henry's constant & $1.76 \times 10^{-12}$ \\
\hline Octonal-water coefficient $($ Kow $)$ & $9.15 \times 10^{-2}-6.74 \times 10^{2}$ \\
\hline Soil adsorption coefficient (Koc) & $0.067-1.1 \mathrm{~cm}^{3} / \mathrm{g}$ \\
\hline
\end{tabular}

Pure 2,4-D can be found as flakes, powder, crystalline powder and solid material. It is white to light tan in color and may be odorless or have a phenolic aroma. The compound is stable at its melting point [5]. 2,4-D forms water soluble salts with alkali metals and amines. 2,4-D is soluble in most organic solvents and is insoluble in benzene and petroleum oils [5]. However, the esters are soluble in oils [8] and are generally formulated as emulsions. Esters of low molecular weight alcohols have relatively high vapor pressures and will readily volatilize [9]. The 2,4-D salts are formulated as aqueous solutions. The physical/chemical properties of 2,4-D can be shown in Table 1. 2,4-D is the part of chlorophenoxy herbicide family of chemical compounds with six number rings containing six carbon atoms. In addition to the phenoxy carbon ring it also contains two chlorine and acetic acid attached to the ring. The chemical name is 2,4-dichlorophenoxyacetic acid and the chemical structure is shown in Figure 1 [10]. 2,4-D is produced from chloroacetic acid and 2,4-D dichlorophenol, which itself produced by chlorination of phenol. Alternatively, it may be produced by the chlorination of phenoxyacetic acid [10].

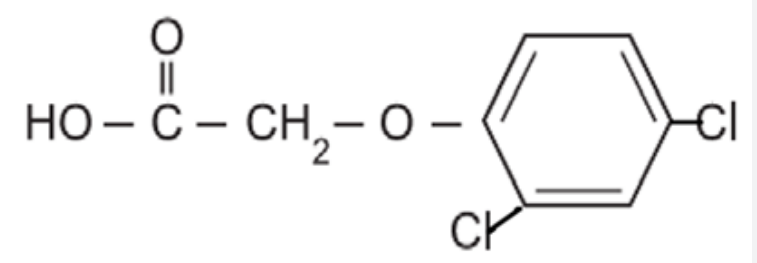

Figure 1: Chemical Structure of 2,4-D.

\section{Environmental Fate and Persistence}

\section{In Air}

Volatilization plays only a minor role in the breakdown and dissipation of the 2,4-D acid due to its low vapor pressure of $1.4 \times 10^{-7} \mathrm{mmHg}$ (Table 1). Further, there is little movement of 2,4-D acid through the air/water barrier, the barrier between atmosphere and surface water or soil moisture, into air due to a low Henry's Law Constant of $1.76 \times 10^{-12} \mathrm{ppm}$ [14] (Table 1).

The primary source of 2,4-D in air is drift from spray applications of the herbicide [10]. If proper application techniques are not used, the high volatile esters may be prone to spray drift causing toxic effects in nearby crops [15]. With the exception of the high volatile ester formulations, the small amount of 2,4-D that gets into the air is subject to photo oxidation by reaction with hydroxyl radicals with an estimated half-life of one day [10] or dissolves into water droplets and is transported back to the earth's surface via wet deposition. The low volatile ester and amine formulations are used in forests so drift from those applications is relatively negligible [15].

\section{In Water}

In the aqueous environment, 2,4-D is most commonly found as the free anion [16]. The amine salt formulations dissociate to the anion and ester formulations hydrolyze to the anion, usually within one day [15]. The rate of hydrolysis is $\mathrm{pH}$ dependent, with the hydrolysis half-life at $\mathrm{pH} 9$ much shorter than the halflife at pH $6[15,17]$. Therefore, the persistence of the 2,4-D anion is of primary concern. Residues of 2,4-D can enter ponds and streams by direct application or accidental drift; by inflow of herbicide previously deposited in dry streambeds, pond bottoms, or irrigation channels; runoff from soils; or by leaching through the soil column [18]. Groundwater contribution of 2,4-D residues into ponds and streams is dependent upon soil type, with coarsegrained sandy soils with low organic content expected to leach 2,4-D into groundwater [10]. Transport losses from forest soils to water bodies are expected to be less than losses from agricultural soils due to factors such as reduced surface runoff, adsorption to forest litter, absorption by plants, and possible greater organic material and microbial activity in forest soils [9].

Decomposition of the anion appears to result from microbial or photodegradation, with photolysis playing a minor role if microbial degradation is rapid. Both aerobic and anaerobic degradation are possible, although anaerobic degradation is relatively slow with a half-life of 312 days (Table 1). In water, 2,4-D will biodegrade at a rate dependent upon the level of nutrients present, temperature, availability of oxygen, and whether the water has been previously contaminated with 2,4-D or other phenoxy acetic acids [10]. Microbial degradation is a possible route for the breakdown of 2,4-D, but it is very dependent on the characteristics of the water.

Laboratory studies have shown that in warm, nutrient rich water that has been previously treated with 2,4-D microbial 
degradation can be a major factor for dissipation [16]. Natural surface waters are generally cool with nutrient concentrations less than those needed to maintain 2,4-D degrading microorganism populations [15]. These conditions would not promote the growth of microorganisms needed to achieve microbial degradation. Microbial metabolism has been found to be biphasic with the first phase being a lag phase where the microbes acclimate to the test compound and the second phase being rapid metabolism with a total half-life of 15 days for both phases [13]. Cohen reports 2-chlorohydroquinone (1,4-dihydroxy 2-chlorophenol) as the major metabolite and 2,4-dichlorophenol and carbon dioxide as minor metabolites. Anaerobic aquatic metabolism is a minor pathway with a half-life of 312 days (Table 1). Major metabolites are 2,4-DCP and carbon dioxide, with 4-chlorophenol and 2,4-dichloroanisol (2,4-DCA) as minor metabolites [12].

2,4-D has an aqueous photolysis half-life of 13 days at $25^{\circ} \mathrm{C}$ at the surface of distilled water (Table 1). In natural surface waters photodecomposition is not expected to be significant due to weaker ultraviolet radiation of natural sunlight and the presence of suspended and organic matter which reduces the effects of solar radiation [15]. The half-life is expected to increase with depth due to reduction in penetration. According to a study by the Industry Task Force on 2,4-D, the major photodegradation product is 1,2,4-benzenetriol [19]. Additional studies showed that 2,4$\mathrm{D}$ is susceptible to photodegradation resulting in the formation of carbon dioxide, 1,2,4-benzenetriol, 2,4- dichlorophenol and then proceeds to a secondary photolysis forming humic acids $[20,21]$. For high volatile ester formulations of $2,4-\mathrm{D}$, volatilization may play a larger role for removal from water than hydrolysis. In neutral and acidic waters conversion from ester to anion via hydrolysis is slower than the potential rate of vaporization [15].

\section{In Soil}

In soil, 2,4-D esters and salts are first converted to the parent acid prior to degradation. The rate of the ester hydrolysis decreases with decreasing soil moisture and with increasing molecular weight of the alcohol portion of the ester. The fate of 2,4-D may be affected by several processes including runoff, adsorption, chemical and microbial degradation, photodecomposition, and leaching [22]. Water solubility and the soil adsorption coefficient (Koc) indicate the potential mobility of a chemical in soil; while the aerobic and anaerobic soil metabolism, hydrolysis half-lives, and field dissipation rate indicate the persistence of a chemical in soil [23]. 2,4-D has a moderate persistence in soil with a field dissipation half-life of 59.3 days, aerobic half-life of 66 days, and a hydrolysis half-life of 39 days (Table 1).

As Hermosin \& Cornejo [24] reported that by using a simple regression analysis between adsorption capacities and soil properties, they found that high organic matter and free iron in soils favored the adsorption of 2,4-D, while high $\mathrm{pH}$, large surface area, and phyllosilicates as essential clay components decreased adsorption. 2,4-D is in nonionic form at $\mathrm{pH}$ less than 6 and is in anionic form at $\mathrm{pH}$ greater than 6. In slightly acidic soils, 2,4-D will be adsorbed at pH less than 6 but will not be adsorbed as much if in the anionic form because the negative charges of the soil and chemical repel each other [25].

Microbial degradation is the major route in the breakdown of 2,4-D in soil. The most important mechanism of microbial degradation involves the removal of the acetic acid side chain to yield 2,4-DCP. This is followed by ring cleavage and degradation to produce aliphatic acids such as succinic acid [15]. The rate of microbial degradation is dependent upon the water potential, depth and temperature of the soil. Han and New [26] found that sandy loam soil containing 2,4-D degrading single-celled bacteria, filamentous bacteria (actinomycetes), and fungi had the lowest degradation rates at a low water potential of -5.5 $\mathrm{MPa}$ (megapascals), with -0.1 MPa corresponding to soils at or below field capacity. An increase in water potential resulted in increased rates of breakdown [26].

Dry soil conditions contribute to the inhibition of 2,4D mineralization by restricting solute mobility, reducing the herbicide degrading activity of organisms, and suppressing the 2,4D degrading microorganism populations. Under dry conditions the addition of organic matter may enhance degradation by simulating the co-metabolizing fungal and actinomycete communities [26]. The rate of microbial degradation is also dependent on soil depth and temperature, with rates of degradation decreasing with increased depths and lower temperatures [27].

Degradation in soil is affected by the rate of adsorptiondesorption of 2,4-D onto soil particles which bind the chemical, making it unavailable for microbial degradation [28]. Bolan and Baskaran also found that as soil organic carbon content increased to $12 \%$ the rate of adsorption increased correlating to a decreased rate of degradation due to low concentrations of 2,4-D available for microbial degradation. But when the organic carbon content was more than $12 \%$ there was an increase in the rate of both adsorption and degradation.

The enhanced degradation of 2,4-D was attributed to the increased biological activity of the soil and the decreased 2,4-D-induced inhibitory effect on microbial activity [28]. Benoit et al. have also demonstrated the importance of soil organic matter in the sorption of 2,4-D. Lignin from plant tissue or aliphatic compounds from microbial origin contributed to increased sorption, while compounds such as soluble tannins decreased sorption [29]. This indicates that the addition of lignin or aliphatic compounds to soil may decrease the rate of degradation, while the addition of soluble tannins may increase the rate of degradation.

Photodecomposition on soil surfaces plays a very minor role in the breakdown of 2,4-D and only occurs on the upper surface of the soil. In a photolysis study conducted by the Industry Task Force on 2,4-D, no degradation products were found at concentrations above $1.1 \%$ of the initially applied compound indicating that 2,4-D is very resistant to soil photodegradation [30]. Another study conducted by the EPA was unsuccessful in identifying the photodegradation products [21]. 
The high-water solubility of $4.46 \times 10^{4} \mathrm{ppm}$ and low soil adsorption coefficient of $0.067-1.1 \mathrm{~cm}^{3} / \mathrm{g}$ (Table 1) for the 2,4-D free acid suggests that it has a high potential to leach in soil. The principal means of movement would probably be with percolating water, while diffusion is important only for transport over small distances [10]. The adsorption capacity of a given soil affects the potential for leaching of 2,4-D; in soils that promote adsorption, the leaching potential is lower. 2,4-D adsorption has been correlated with the organic content.

Grover [31] found that higher volumes of water were required to leach 2,4-D from soils with a high organic content. Further, leaching was correlated with the $\mathrm{pH}$ of soils; 2,4-D leached more readily in soils with pH's of 7.5 and above [30] reflecting higher adsorption to organic matter in more acidic soils [25]. However, despite its potential mobility, 2,4-D generally remains within the top few inches of the soil $[15,32]$ found that most of the 2,4-D, applied at a rate of $4.49 \mathrm{~kg} / \mathrm{ha}$ in the ester form to nursery plots with varying crop covers, remained in the top $20 \mathrm{~cm}$ of the soil. Norris [18] states that entry via leaching is not an important process for transporting significant quantities of 2,4-D into streams since it is adsorbed onto organic material and is readily degraded by microorganisms.

The extent of leaching and runoff of 2,4-D is influenced by the formulation, soil properties, slope, and timing and intensity of rainfall. 2,4-D was found susceptible to runoff if the rain event occurred shortly after the application, with runoff concentrations decreasing over time [32]. Esters form of 2,4-D do not leach into soil as readily as the more soluble formulations, they have a greater potential to be carried in surface runoff [15]. Wilson \& Cheng [33] studied the iso octyl ester and dimethylamine salt formulations of 2,4-D and found that both formulations are subject to similar surface runoff within a few days after application if enough rainfall occurs.

\section{In Plants}

In plants, 2,4-D formulations having high lipid solubility (such as the esters) rapidly penetrate the cuticle. An oil carrier is usually added to water soluble formulations to enhance penetration. Salt formulations are most readily absorbed through the roots, while esters are more readily absorbed through foliage. Foliar applied 2,4-D is easily translocated in the phloem and carried with material from photosynthesizing leaves to growth sites where it accumulates. Translocation of 2,4-D upward by roots takes place primarily in the transpiration stream of the xylem [23].

The rate of translocation of the compound is affected by environmental conditions such as soil moisture and atmospheric humidity [8]. 2,4-D mimics the effects of auxins (plant growth regulators) and is found to persist in plant tissues longer than the natural hormone. Ester formulations do not function as growth regulators until they are converted to the acid form, usually within $1 / 2$ hour after application [8]. The immediate cause of plant death is due to abnormal metabolism of nucleic acids [8]. Plants metabolize 2,4-D by degradation of the side chain, hydroxylation of the ring structure (addition of $\mathrm{OH}^{-}$), conjugation of 2,4-D with plant constituents, formation of metabolites, ring cleavage, or side chain lengthening [23]. 2,4-D resistant plants convert the chemical into inactive, nontoxic carbohydrate conjugates, while susceptible plants convert it into amino acid conjugates which obstruct normal nucleic acid metabolism and protein synthesis $[8,15]$.

\section{Toxicity to Animals and Humans}

Table 2: Toxicity of 2,4-D to some animals and other species, Adapted from: $[6,37-38]$.

\begin{tabular}{|c|c|}
\hline Animals & Toxicity level \\
\hline Rat (acute, oral) & $\mathrm{LD}_{50} 639-1646 \mathrm{mg} / \mathrm{Kg}$ \\
\hline Mice & $\mathrm{LD}_{50} 138 \mathrm{mg} / \mathrm{Kg}$ \\
\hline Rat (acute, inhalation) & $\mathrm{LD}_{50} 0.78-5.4 \mathrm{mg} / \mathrm{Kg}$ \\
\hline Rabbit (acute, percutaneous) & $\mathrm{LD}_{50}>1829$ to $>2000 \mathrm{mg} / \mathrm{L}$ \\
\hline Wild ducks (acute, oral) & $\mathrm{LD}_{50}>1000 \mathrm{mg} / \mathrm{Kg}$ \\
\hline Japanese quail (acute, oral) & $\mathrm{LD}_{50} 668 \mathrm{mg} / \mathrm{Kg}$ \\
\hline Pigeons (acute, oral) & $\mathrm{LD}_{50} 668 \mathrm{mg} / \mathrm{Kg}$ \\
\hline Pheasants (acute, oral) & $\mathrm{LD}_{50} 472 \mathrm{mg} / \mathrm{Kg}$ \\
\hline Dog & $\mathrm{LD}_{50} 100 \mathrm{mg} / \mathrm{Kg}$ \\
\hline Chicken & $\mathrm{LD}_{50} 540 \mathrm{mg} / \mathrm{Kg}$ \\
\hline Honeybees & - \\
\hline Rainbow trout (48 hour) & $\mathrm{LC}_{50} 100 \mathrm{mg} / \mathrm{L}$ \\
\hline Earth worm & $\mathrm{Lc}_{50} 61.6 \mu \mathrm{g} / \mathrm{mL}$ \\
\hline Bluegills (48 hour) & $\mathrm{LC}_{50} 0.9 \mathrm{mg} / \mathrm{L}$ \\
\hline Striped bass ( 96 hour) & $\mathrm{LC}_{50} 70 \mathrm{mg} / \mathrm{L}$ \\
\hline Fish and aquatic life & $\mathrm{LC}_{50} 80-2244 \mathrm{mg} / \mathrm{L}$ \\
\hline Pumpkinseed (96 hour) & $\mathrm{LC}_{50} 65 \mathrm{mg} / \mathrm{L}$ \\
\hline White perch (96 hour) & $\mathrm{LC}_{50} 40 \mathrm{mg} / \mathrm{L}$ \\
\hline American eel (96 hour) & $\mathrm{LC}_{50} 300 \mathrm{mg} / \mathrm{L}$ \\
\hline Crap (96 hour) & $\mathrm{LC}_{50} 96.5 \mathrm{mg} / \mathrm{L}$ \\
\hline Guppy (96 hour) & $\mathrm{LC}_{50} 70.7 \mathrm{mg} / \mathrm{L}$ \\
\hline Dapnia (48 hour) & $\mathrm{LC}_{50} 5.2 \mathrm{mg} / \mathrm{L}$ \\
\hline
\end{tabular}

Toxicity of pesticides can be classified into neurotoxicity, genotoxicity, cytotoxicity, hepatotoxicity and many more. Toxicity can be defined as negative effect of certain substance that capable of damaging the structure or any processes which are vital for organism survival [34]. Factors that influence the herbicide toxicity are concentration, frequency, intensity of exposure and target organism susceptibility, which is depend on age, sex, health state and genetic variations $[35,36]$. Among herbicides, phenoxyacetic acid showed hepatotoxic and nephrotoxic effects in animal studies when they are exposed to high level of these herbicides. Toxicity of 2,4-D to some animals and other species shown in (Table 2).

$\mathrm{LD}_{50} / \mathrm{LC}_{50}: \mathrm{A}$ common measure of acute toxicity is the lethal dose $\left(\mathrm{LD}_{50}\right)$ or lethal concentration $\left(\mathrm{LC}_{50}\right)$ that causes death (resulting from a single or limited exposure) in 50 percent of the treated animals. $\mathrm{LD}_{50}$ is generally expressed as the dose in milligrams (mg) of chemical per kilogram $(\mathrm{kg})$ of body weight. 
$\mathrm{LC}_{50}$ is often expressed as mg of chemical per volume (e.g., liter (L)) of medium (i.e., air or water) the organism is exposed to. Chemicals are considered highly toxic when the $\mathrm{LD}_{50} / \mathrm{LC}_{50}$ is small and practically non-toxic when the value is large. However, the $\mathrm{LD}_{50} / \mathrm{LC}_{50}$ does not reflect any effects from long-term exposure (i.e., cancer, birth defects or reproductive toxicity) that may occur at levels below those that cause death [39-42]. The toxicity of 2,4D may be classified as high toxicity, moderate toxicity, low toxicity and very low toxicity. These classifications are depending on acute toxicity: oral, dermal, inhalation and others. Toxicity classification of 2,4-D shown in (Table 3).

Table 3: Toxicity classification of 2,4-D, Adapted from: [5,39,40,42,43].

\begin{tabular}{|c|c|c|c|c|}
\hline Toxicity Level & High Toxicity & Moderate Toxicity & Low Toxicity & Very Low Toxicity \\
\hline Acute Oral $\mathrm{LD}_{50}$ & $\begin{array}{l}\text { Up to and including } 50 \mathrm{mg} / \mathrm{Kg}(\leq \\
50 \mathrm{mg} / \mathrm{Kg})\end{array}$ & $\begin{array}{l}\text { Greater than } 50 \text { through } 500 \text { (> } \\
50-500 \mathrm{mg} / \mathrm{Kg})\end{array}$ & $\begin{array}{l}\text { Greater than } 500 \text { through } \\
5000(>500-5000 \mathrm{mg} / \mathrm{Kg})\end{array}$ & $\begin{array}{r}\text { Greater than } 5000 \\
5000 \mathrm{mg} / \mathrm{Kg})\end{array}$ \\
\hline Inhalation $\mathrm{LC}_{50}$ & $\begin{array}{l}\text { Up to and including } 0.05 \mathrm{mg} / \mathrm{L}(\leq \\
0.05 \mathrm{mg} / \mathrm{Kg})\end{array}$ & $\begin{array}{l}\text { Greater than } 0.05 \text { through } \\
0.5 \mathrm{mg} / \mathrm{L}(>0.05-0.5 \mathrm{mg} / \mathrm{L})\end{array}$ & $\begin{array}{l}\text { Greater than } 0.5 \text { through } \\
0.2 \mathrm{mg} / \mathrm{L}(>0.5-0.2 \mathrm{mg} / \mathrm{L})\end{array}$ & $\begin{array}{c}\text { Greater than } 0.2 \mathrm{mg} / \mathrm{L}(> \\
0.2 \mathrm{mg} / \mathrm{L})\end{array}$ \\
\hline Dermal LD ${ }_{50}$ & $\begin{array}{l}\text { Up to and including } 200 \mathrm{mg} / \mathrm{L}(\leq \\
200 \mathrm{mg} / \mathrm{Kg} \text { ) }\end{array}$ & $\begin{array}{c}\text { Greater than } 200 \text { through } \\
2000 \mathrm{mg} / \mathrm{Kg}(>200-2000 \mathrm{mg} / \\
\mathrm{Kg})\end{array}$ & $\begin{array}{c}\text { Greater than } 2000 \text { through } \\
5000 \mathrm{mg} / \mathrm{Kg}(>2000-5000 \\
\mathrm{mg} / \mathrm{Kg})\end{array}$ & $\begin{array}{c}\text { Greater than } 5000 \mathrm{mg} / \mathrm{Kg} \\
\text { (> } 5000 \mathrm{mg} / \mathrm{Kg})\end{array}$ \\
\hline $\begin{array}{l}\text { Primary eye } \\
\text { Irritation }\end{array}$ & $\begin{array}{l}\text { Corrosive (irreversible destruction } \\
\quad \text { of ocular tissue) or corneal } \\
\text { involvement or irritation persisting } \\
\text { for more than } 21 \text { days (Acid, Ester) }\end{array}$ & $\begin{array}{l}\text { Corneal involvement or other } \\
\text { eye irritation clearing in } 8-21 \\
\text { days }\end{array}$ & $\begin{array}{l}\text { Corneal involvement or other } \\
\text { eye irritation clearing in } 7 \\
\text { days or less (Ester) }\end{array}$ & $\begin{array}{l}\text { Minimal effects clearing } \\
\text { in less than } 24 \text { hours } \\
\text { (Ester) }\end{array}$ \\
\hline $\begin{array}{l}\text { Primary skin } \\
\text { irritation }\end{array}$ & $\begin{array}{l}\text { Corrosive (tissue destruction into } \\
\text { the dermis and/or scarring) }\end{array}$ & $\begin{array}{l}\text { Severe irritation at } 72 \text { hours } \\
\text { (severe erythema or edema) }\end{array}$ & $\begin{array}{c}\text { Moderate irritation at } 72 \\
\text { hours (moderate erythema) }\end{array}$ & $\begin{array}{l}\text { Mild or slight irritation at } \\
72 \text { hours (no irritation or } \\
\text { erythema) (Ester, Salt) }\end{array}$ \\
\hline
\end{tabular}

\section{Acute Toxicity}

$\mathrm{LD}_{50}$ values range from $639 \mathrm{mg} / \mathrm{kg}$ to $1646 \mathrm{mg} / \mathrm{kg}$ in rats depending on the chemical form of 2,4-D utilized in the study [39]. Researchers found that 2,4-D was more toxic for mice, reporting an $\mathrm{LD}_{50}$ of $138 \mathrm{mg} / \mathrm{kg}$ [40]. All chemical forms for 2,4-D are considered low in toxicity for acute oral exposure based on tests with rats $[39,43]$ (Table 2). Acute dermal $L_{50}$ s ranged from 1829 $\mathrm{mg} / \mathrm{kg}$ to greater than $2000 \mathrm{mg} / \mathrm{kg}$ in rabbits depending on the chemical form of 2,4-D. All chemical forms of 2,4-D are considered low in toxicity for acute dermal exposure based on studies using rabbits [39].

The acid and salt forms of 2,4-D are highly toxic to eye tissue, causing severe eye irritation. This is reflected in the signal word of the formulated product. The ester forms are not considered eye irritants and have low to very low ocular toxicity (Table 3). The ester and salt forms of 2,4-D are considered slight skin irritants [39]. All chemical forms of 2,4-D are of low to very low toxicity via inhalation based on studies using rats. Acute inhalation $\mathrm{LC}_{50} \mathrm{~s}$ for rats ranged from $0.78 \mathrm{mg} / \mathrm{L}$ to greater than $5.4 \mathrm{mg} / \mathrm{L}$ depending on the chemical form. Most forms of 2,4-D are very low in toxicity, and the parent acid and tri-isopropanol amine (TIPA) salt forms are low in toxicity [39].

\section{Signs of Toxicity to Animals}

Dogs fed 2,4-D exhibited myotonia, vomiting, and weakness; dogs are more sensitive to chlorophenoxy acid herbicides than other animals [44]. In addition, dogs and cats have displayed inappetence, anorexia, ataxia, salivation, diarrhea, lethargy, and convulsions following exposure to 2,4-D, which may include eating treated grass [45] although the potential for this is unclear [46]. Rats demonstrated incoordination, central nervous system depression and muscular weakness following acute oral dosing
$[39,47]$. Biochemical analysis of rat tissues suggested hepatic and muscle damage following acute, sub chronic, and chronic oral exposures [47].

\section{Signs of Toxicity to Humans}

No occupational studies were found reporting signs or symptoms following exposure to 2,4-D under normal usage. Symptoms of acute oral exposure to 2,4-D include vomiting, diarrhea, headache, confusion, aggressive or bizarre behavior. A peculiar odor is sometimes noted on the breath. Skeletal muscle injury and renal failure may also occur. Systemic toxicity is mainly associated with suicide attempts [48]. Symptoms following dermal exposure may include irritation, and inhalation exposure may lead to coughing and burning sensations in the upper respiratory tract and chest. Prolonged exposure may result in dizziness [48].

Chlorophenoxy compounds such as 2,4-D are quickly absorbed when swallowed, but absorption from dermal or inhalation exposure is low $[48,49]$. Case reports and observational studies provide most of the information regarding the toxicological effects of 2,4-D in incidents involving human poisonings. Researchers compiled the medical cases of 69 people who ingested 2,4-D and other chlorophenoxy herbicides; 23 of these patients died [49]. Ingestion led to vomiting, abdominal pain, diarrhea, and development of hypotension. Peripheral neuromuscular effects including muscle twitching, weakness, and loss of tendon reflexes have been reported. Neuromuscular effects have lasted several weeks to months and have been permanent in some cases [49].

\section{Chronic Toxicity}

\section{Animals}

Sub-chronic oral exposure to 2,4-D caused damage to the eye, thyroid, kidney, adrenals, and the ovaries and testes of laboratory 
animals [39,50]. A sub-chronic no observable effect level was established at $15 \mathrm{mg} / \mathrm{kg} /$ day based on studies in rats [50]. The chronic toxicity no observable effect level (NOEL) in rats and mice was determined to be $5 \mathrm{mg} / \mathrm{kg} /$ day in two-year studies [43,51]. The maximum tolerated dose in the two-year rat study was 150 $\mathrm{mg} / \mathrm{kg} /$ day in male rats and $75 \mathrm{mg} / \mathrm{kg} /$ day in females [50]. Additional no observable effect level (NOEL) and no observable adverse effect level (NOAEL) doses were $15 \mathrm{mg} / \mathrm{kg}$ for rats in a 90day study, and $1 \mathrm{mg} / \mathrm{kg}$ for dogs in a 12-month study, respectively $[43,52]$. Rabbits exhibited toxicity following dosing with either acid, salt, or ester forms of 2,4-D at doses of $30 \mathrm{mg} / \mathrm{kg} /$ day or greater [53].

Chronic no observable adverse effect levels (NOAEL) and lowest observable effect levels (LOEL) in dogs, however, varied for different parameters studied and by chemical form [52]. Rats showed no outward signs of toxicity following exposure to $200 \mathrm{mg} / \mathrm{L}$ of 2,4-D in drinking water for 30 and 100 days, but biochemical analysis suggested hepatic and muscle damage [47]. Researchers fed rats 2,4-D at doses of 1, 15, 100, and 300 $\mathrm{mg} / \mathrm{kg} /$ day acid equivalents (ae). Changes in blood and thyroid parameters, organ weight ratios, and body weight gain were noted at 100 and $300 \mathrm{mg} / \mathrm{kg} /$ day doses [50]. Chronic toxicity in the eye, kidney, thyroid and liver of the rat were like effects found in subchronic studies [51]. Eye lesions were associated only with high doses of $150 \mathrm{mg} / \mathrm{kg} /$ day [51].

\section{Humans}

No human data were found on chronic effects of 2,4-D other than epidemiological studies of cancer occurrence. Although pesticide use has been linked to Parkinson's disease and to respiratory disease in farmers, 2,4-D was not implicated in any relationships between pesticide exposure and subsequent disease [54-55].

\section{Carcinogenicity}

\section{Animals}

No oncogenic effects were observed in rats or mice following 2 years of dietary exposure of 2,4-D with concentrations ranging from $5-150 \mathrm{mg} / \mathrm{kg} /$ day or $5-300 \mathrm{mg} / \mathrm{kg} /$ day, respectively [51]. Similarly, researchers did not observe immune-toxic or oncogenic responses in dogs dosed with $1.0-7.5 \mathrm{mg} / \mathrm{kg} /$ day for either 13 weeks or 1 year [52]. A case-control study in companion dogs concluded that there was a "modest association" between malignant lymphoma in the dogs and the use of 2,4-D in their owners' yards after accounting for other home and yard pesticide use [56]. Other investigators have questioned the epidemiological association reported in that study $[57,58]$. Overall, there has been no consistent association between exposure to 2,4-D and tumor induction in animals [59]. More recently, non-cytotoxic concentrations of 2,4-D were correlated to DNA damage and altered expression of some genes in hamster embryo cells [60].

\section{Humans}

The U.S. EPA evaluated 2,4-D for carcinogenic effects in 1988,
1992, and again in 2004. Each evaluation has concluded that "the data are not sufficient to conclude that there is a cause and effect relationship between exposure to 2,4-D and non- Hodgkin's Lymphoma." 2,4-D was categorized as "Group D - not classifiable as to human carcinogenicity" in 2004 [39]. The International Agency for Research on Cancer (IARC), had not assigned 2,4-D a cancer rating as of June 2008 . However, in 1987, IARC placed the family of chlorophenoxy herbicides in Group 2B, possibly carcinogenic to humans [61].

A discussion of the history of classification decisions regarding the carcinogenicity of 2,4-D has been published. A confounding factor in determining the carcinogenicity of 2,4-D is the frequent simultaneous exposure of workers to 2,4-D in addition to 2,4,5$\mathrm{T}$ and its contaminant tetrachlorodibenzo-p-dioxin (TCDD), or to other herbicides. However, other work examining incidents of exposure to 2,4-D without simultaneous exposure to 2,4,5-T has found some association between 2,4-D and non-Hodgkin's lymphoma [58]. Although the free acid form of 2,4-D did not damage chromosomes, there is limited evidence that commercial formulations may have the potential to do so [59]. Overall, evidence for mutagenicity has been inconsistent $[58,59,62]$.

\section{Reproductive or Teratogenic Effects}

\section{Animals}

Teratogenic effects were not observed in mice, rats, or rabbits unless the excretion capacity of the mother was overwhelmed following oral exposure to 2,4-D or its salt and ester forms [53,59]. Reduced fetal viability was observed in hamsters following maternal dosing at $40 \mathrm{mg} / \mathrm{kg} /$ day during pregnancy, although effects did not follow a dose-response relationship [63]. Fetal abnormalities were observed in rats following oral doses of 90 $\mathrm{mg} / \mathrm{kg} /$ day or greater beginning at fertilization; these doses were toxic to the mothers as well [53]. A no observable effect level (NOEL) of $25 \mathrm{mg} / \mathrm{kg} /$ day was derived for fetal rats in one study, and a no observable adverse effect level of $12.5 \mathrm{mg} / \mathrm{kg} /$ day for the mothers and a developmental no observable adverse effect level (NOEL) of $50 \mathrm{mg} / \mathrm{kg} /$ day for the young were derived in another study [1].

The overall maternal no observable effect level (NOEL) in rats was determined to be $8-17 \mathrm{mg} / \mathrm{kg} /$ day and overall developmental no observable effect level was $30 \mathrm{mg} / \mathrm{kg} /$ day 2,4-D acid equivalents [53]. Rabbit fetuses were unaffected at doses below $40 \mathrm{mg} / \mathrm{kg} /$ day administered to the dams although extra ribs were formed at doses above this threshold [53]. In rabbits, the developmental no observable effect level (NOEL) was $30 \mathrm{mg} / \mathrm{kg} /$ day 2,4-D acid equivalents [53].

\section{Humans}

No experimental data are available regarding the effects of 2,4-D exposure on reproduction or development in humans. There are some reports of reproductive effects following occupational exposure to chlorophenoxy herbicides, [1] including reduced sperm motility and viability following occupational exposure. 
Although motility and viability recovered over a period of several months, malformations were still present [64]. Exposure to multiple pesticides in epidemiological studies makes inference difficult [59].

\section{Ecotoxicity Studies}

\section{Birds}

$\mathrm{LD}_{50}$ values range from $472 \mathrm{mg} / \mathrm{kg}$ for acute oral exposure in pheasants, to $668 \mathrm{mg} / \mathrm{kg}$ in pigeons and Japanese quail, to greater than $1000 \mathrm{mg} / \mathrm{kg}$ in wild ducks [40] (Table 3). The acute oral $\mathrm{LD}_{50}$ for the dimethyl amine salt form of the compound was $500 \mathrm{mg} /$ $\mathrm{kg}$ for bobwhite quail, and the acute oral $\mathrm{LD}_{50}$ for the ethyl hexyl form was $663 \mathrm{mg} / \mathrm{kg}$ in mallard ducks. The acute oral $\mathrm{LD}_{50}$ for wild ducks was in excess of $2025 \mathrm{mg} / \mathrm{kg}$ for the sodium salt form of 2,4-D [40]. Overall, 2,4-D is moderately toxic to practically nontoxic to birds. There are no pronounced differences in toxicity based on the form of 2,4-D [39]. Five-day studies estimated $\mathrm{LC}_{50}$ values for bobwhite quail and mallard ducks at greater than 5620 ppm [40]. Chronic studies have also demonstrated low toxicity, with no effects observed below very high exposure levels such as concentrations in drinking water greater than the solubility of the chemical [42]. Under field conditions, eggs of ground-nesting birds could be exposed, but eggshell permeability to 2,4-D is low and treating eggshells with high concentrations of 2,4-D did not reduce hatchability or cause chick abnormalities [42].

\section{Fish and Aquatic Life}

Toxicity to fish and aquatic invertebrates varies widely depending on chemical form, with esters being the most toxic [40,42]. Acid and amine salt $\mathrm{LC}_{50}$ s range from greater than 80 to $2244 \mathrm{mg}$ acid equivalents per liter ( $\mathrm{mg}$ ae/L) whereas the esters range from less than 1.0 to $14.5 \mathrm{mg}$ acid equivalents per liter [39]. The greater toxicity generally of the esters in fish is likely due to the greater absorption rates of the esters through the gills, where they are hydrolyzed to the acid form [42].The acute $\mathrm{LC}_{50}$ of the dimethyl amine salt form to rainbow trout was $100 \mathrm{mg} / \mathrm{L}$, which is considered slightly toxic [40] (Table 3).

The acute $\mathrm{LC}_{50}$ of the ethyl hexyl form to rainbow trout was greater than its solubility in water [40]. The $\mathrm{LD}_{50}$ value for the isoctyl form in cutthroat trout was $0.5-1.2 \mathrm{mg} / \mathrm{L}$, [39] or moderately to highly toxic. Adult fathead minnows exhibited toxic effects at chronic exposures of the butoxyl ethanol ester form that were 1:10 to 1: 45 of the 96-hour $\mathrm{LC}_{50}$ concentrations [42]. Early life stages of fish are more susceptible compared with adult fish or eggs [42] (Table 3).

Daphnia exposed to the acid form for 21 days exhibited an $\mathrm{LC}_{50}$ of $235 \mathrm{mg} / \mathrm{L}$ when exposed to 2,4-D acid for 21 days, and an $\mathrm{LC}_{50}$ of $5.2 \mathrm{mg} / \mathrm{L}$ when exposed to the ethyl hexyl form for 48 hours [40]. Therefore, the acid form is practically non-toxic to Daphnia, but the ethyl hexyl form is moderately toxic. As with fish, esters are more toxic than acid or amine salt forms to freshwater aquatic invertebrates, with $\mathrm{LC}_{50}$ values ranging from 25 to $643 \mathrm{mg}$ ae/ $\mathrm{L}$ for the acid and amine salt forms but 2.2 to $11.8 \mathrm{mg}$ ae/L for esters
[39]. The relative toxicities for acids and salts are slightly toxic to practically non-toxic, whereas the esters are moderately to slightly toxic (Table 3).

Marine invertebrate sensitivities are like aquatic invertebrates, with $\mathrm{LC}_{50}$ values of $50-830 \mathrm{mg}$ ae/L for acid and salt forms and $>0.092$ to $>66 \mathrm{mg}$ ae/L for ester forms [39]. The corresponding relative toxicity values are slightly toxic to practically non-toxic for the salts and acid but highly toxic to practically non-toxic for the ester forms. Researchers have estimated a No Observed Effect Concentration (NOEC) of $16.1 \mathrm{mg}$ ae/L for the DEA ester and 79.0 $\mathrm{mg}$ ae/L for the acid form based on survival and reproduction for diethanolamine salt (DEA) and number of young produced for the acid form. The freshwater aquatic invertebrate No Observed Effect Concentration (NOEC) for the butoxyethyl ester (BEE) was estimated at $0.2 \mathrm{mg}$ ae/L based on survival and reproduction [39].

2,4-D is marketed for controlling aquatic plants. Therefore, the lethal concentrations (LC) are reported as effective concentrations (EC) for killing half the target population $\left(\mathrm{EC}_{50}\right)$. Researchers estimated an $\mathrm{EC}_{50}$ of $0.58 \mathrm{mg} / \mathrm{L}$ for duckweed (Lemna gibba). A variety of algal species exhibited $\mathrm{LC}_{50}$ values ranging between 0.23 and greater than $30 \mathrm{mg} / \mathrm{L}$ for the ethyl hexyl form [40]. The $\mathrm{EC}_{50}$ for the dimethyl amine salt form against Selenastrum capricornutum was estimated at $51.2 \mathrm{mg} / \mathrm{L}$ [40]. No effects were recorded for 19 genera of algae exposed to 2,4-D at concentrations of up to 222 $\mathrm{mg} / \mathrm{L}$. However, the ester forms were toxic to some algae at much lower concentrations [42].

A mesocosm study indicated that an unspecified form of 2,4-D applied at $0.117 \mathrm{~mL} / \mathrm{m}^{2}$ had no negative effects on species richness, biomass, or survival on algae and 25 species of aquatic animals, including frog larvae, salamanders, snails, and a range of other invertebrates [65]. 96-hour $\mathrm{LC}_{50}$ concentrations for several species of amphibian larvae exceeded $100 \mathrm{mg} / \mathrm{L}$ for the amine salt forms. 2,4-D acid, 2,4-D ethylhexyl ester (EHE), and 2,4-D dimethylamine (DMA) are considered practically non-toxic to amphibian larvae based on tests with Rana pipiens [39].

Bioavailability and uptake of 2,4-D by organisms are strongly influenced by $\mathrm{pH}$, temperature, and other environmental factors [42]. The sensitivity of aquatic invertebrates to 2,4-D increases with temperature; concentrations below those associated with short-term toxic effects impaired reproduction when ambient temperature was elevated [42]. Although some aquatic invertebrates appear to sense and avoid 2,4-D in the water, others do not, even when exposed to lethal concentrations. Fish appear to avoid 2,4-D in a dose-dependent manner until the onset of toxic effects. Toxicity of 2,4-D was increased when fish were simultaneously exposed to 2,4-D and carbaryl or picloram [42].

\section{Terrestrial Invertebrates}

$\mathrm{LC}_{50}$ values for 24-hour exposures in honeybees (Apis mellifera) were estimated to be 104 and115 $\mu$ g per bee. Researchers estimated the $\mathrm{LD}_{50}$ at greater than $10 \mu \mathrm{g} /$ bee, so 2,4D is considered practically non-toxic [39] (Table 3). Effects on 
bee longevity varied according to dose and 2,4-D form [42]. 2,4$\mathrm{D}$ is not considered hazardous to beneficial insects due to its low insecticidal activity and an adequate safety margin when products containing 2,4-D are used at recommended levels [39,42]. Carabid beetles (Carabidae) exposed to sand dosed with $1 \mathrm{~g} / \mathrm{m}^{2}$ exhibited greater than $50 \%$ mortality after 4 days [42].The calculated 48 hour $\mathrm{LC}_{50}$ concentration for earthworms (Lumbricus rubellus) exposed to filter paper treated with 2,4-D was $61.6 \mu \mathrm{g} / \mathrm{cm}$ [54]. Effects of 2,4-D on soil microorganisms were species-dependent [42].

\section{Conclusion}

2,4-D has been the most widely used herbicide in all over the world. It's popularities among farmers and other users are undeniable. It has given the world a lot of benefits in many ways. Despite its sophisticated contributions, it had caused a lot of problems to the environment. This herbicide had caused contamination in various environmental bodies including water, soil and air. Due to many reasons, its distribution in the environment has become broad and it can pollute the food source. Human and other organisms are exposed to this herbicide and this situation can cause much adverse effect to their health and growth. Many factors influence its fate and persistency in the environment.

The environmental fate and negative impact of the 2,4-D has become a great concern and it is vital to evaluate regularly. Its toxicity effects also become another serious issue as the problems occur globally. The study of its toxicity behavior in animal and human are important and can be used to prevent misuse of this herbicide. Living life such as humans and animals are exposed to 2,4-D by the contaminated air, drinking water, soil and foods or if the human works in the agriculture sector and in the factory that produce 2,4-D. So, factors that influence the 2,4-D toxicity are concentration, frequency, intensity of exposure and target organism susceptibility, which is depend on age, sex, health state and genetic variations. Among herbicides, 2,4-D showed hepatotoxic and nephrotoxic effects in animal studies when they are exposed to high level.

\section{References}

1. Munro Ian C, George L Carlo, Joan C Orr, Kelly G Sund, Ross M Wilson, et al. (1992) A Comprehensive, Integrated Review and Evaluation of the Scientific Evidence Relating to the Safety of the Herbicide 2,4-D. Journal of the American College of Toxicology 11(5): 560-664.

2. Mullison, Wendell R (1987) Environmental Fate of Phenoxy Herbicides. In Fate of Pesticides in the Environment, University of California, p. 3320 .

3. Ayansina A D V, Oso B A (2006) Effect of two commonly used herbicides on soil microflora at two different concentrations. Afr J Biotechnol 5(2): 129-132.

4. Que Hee S S, R G Sutherland (1981) The Phenoxyalkanoic Herbicides, Chemistry, Analysis, and Environmental Pollution, CRC Press, Inc., Boca Raton, Florida, p. 319.

5. EPA (1998) Tolerances and exemptions from tolerances for pesticide chemicals in food. Part 180 in Code of Federal Regulations Title 40, Volume 15 - Protection of the Environment.
6. Johnson R A, E V Wattenberg (1996) Risk assessment of phenoxy herbicides: an overview of the epidemiology and toxicology data. Chapter 3 in Biological and Economic Assessment of Benefits from Use of Phenoxy Herbicides in the United States. O. C. Burnside ed. U.S.D.A. National Impact Assessment Program, Special NAPIAP Report, US, p. 96.

7. Stevens J T, D D Sumner (1991) Herbicides, Handbook of pesticide toxicology, Classes of Pesticides, W J Hayes Jr, E R Laws, Jr (eds), Academic Press, Inc. San Diego, California.

8. Meister, Richard T, Charlotte Sine (1994) Farm Chemicals Handbook. 94 Ohio: Meister Publishing, p. c106.

9. USDA, Forest Service (1984) "Pesticide Background Statements." p.D1-D181. In Agricultural Handbook, Herbicides 1(633).

10. Howard PHE (1991) “2,4-D.” Handbook of Environmental Fate and Exposure Data for Organic Chemicals Lewis Publishers (Chelsea MI), 1: 145-156.

11. Kollman W, R Segawa (1995) Interim Report of the Pesticide Chemistry Database. Environmental Hazards Assessment Program. Department of Pesticide Regulation, California.

12. Concha, Marian, Kathryn Shepler (1994) Anaerobic Aquatic Metabolism of [14C]2,4-D Acid. Dow Elanco, Data package ABM-148646-E, Department of Pesticide Regulation, Sacramento, CA, p. 142-155.

13. Cohen SP (1991) Aerobic Aquatic Metabolism of 2,4-Dichlorophenoxyacetic Acid. Unpublished study, Data package ABM-131348-E, Department of Pesticide Regulation.Sacramento, CA, p. 142-141.

14. Rice C P, Chernyak S M, McConnell L L(1997) Henry's Law Constants for Pesticides Measured as a Function of Temperature and Salinity. J Agric Chem 45: 2291-2298.

15. Ghassemi M, L Fargo, P Painter, S Quinlivan, R Scofield, et al. (1981) Environmental Fates and Impacts of Major Forest Use Pesticides, A-U.S.EPA, Office of Pesticides and Toxic Substances, Washington DC, p. 101-148.

16. Halter M T (1980) 2,4-D in the Aquatic Environment. Section II in Literature Reviews of Four Selected Herbicides: 2,4-D, Dichlobenil, Diquat, and Endothall. Municipality of Metropolitan Seattle, Washington.

17. Wang YS, CG Jaw, YL Chen (1994) Accumulation of 2,4-D and glyphosate in fish and water hyacinth. Water Air Soil Pollut 74: 397-403.

18. Norris LA (1981) The Movement, Persistence, and Fate of the Phenoxy Herbicides and TCDD in the Forest, Residue Reviews, 80: 65-135.

19. Cohen SP, RV Tamma Vithala (1989) Aqueous Photodegradation of 2,4 Dichlorophenoxyacetic Acid in pH 7 Buffered Solution. Unpublished study, Department of Pesticide Regulation. Sacramento, CA, p. 142-122.

20. Crosby DG, HO Tutass (1966) Photodecomposition of 2,4-Dichlorophenoxyacetic Acid. Agricultural and Food Chemistry. 14: 596-599.

21. Hautala RR (1978) Surfactant Effects on Pesticide Photochemistry in Water and Soil. EPA-600/3-78-060, Department of Pesticide Regulation, Sacramento, CA, 142-113.

22. Morgan E R, Brunson MW (2002) Toxicities of Agricultural Pesticides to Selected Aquatic Organisms. SRAC Publication 4600: 1-28.

23. Loos MA (1975) Phenoxy alkanoic Acids. In Herbicides: Chemistry, Degradation, and Model of Action ( $2^{\text {nd }}$ ed) Marcel Dekker, New York.

24. Hermosin MC, J Cornejo (1991) Soil Adsorption of 2,4-D as Affected by the Clay Minerology. Toxicology and Environmental Chemistry. 31-32: 69-77.

25. Hillel, Daniel (1982) Introduction to Soil Physics. Academic Press, US.

26. Han, Sung Ok, Peter B New (1994) Effect of Water Availability on Degradation of 2,4-D) by Soil Microorganisms. Soil Biology and Biochemistry 26(12): 1689-1697. 
27. Veeh RH, WP Inskeep, AK Camper (1996) Soil Depth and Temperature Effects on Microbial Degradation of 2,4-D. Journal of Environmental Quality 25: 5-12.

28. Bolan NS, S Baskaran (1996) Biodegradation of 2,4-D Herbicide as Affected by its Adsorption -Desorption Behavior and Microbial Activity of Soils. Australian Journal of Soil Research 34: 1041-1053.

29. Benoit P, E Barrijso, S Houot, R Calvet (1996) Influence of the Nature of Soil Organic Matter on the Sorption-Desorption of 4-Chlorophenol, 2,4-Dichlorophenol and the Herbicide 2,4- Dichlorophenoxyacetic acid (2,4-D). European Journal of Soil Science 47: 567-578.

30. Tamma Vithala, Rama V (1989) Photodegradation of 2,4-Dichlorophenoxyacetic Acid on Soil. Unpublished study, Artment of Pesticide Regulation, Sacramento, CA, 142-1D2e2p.

31. Grover R (1977) Mobility of Dicamba , Picloram, and 2,4-D in Soil Columns. Weed Science 25: 159-162.

32. Stearman G Kim, Martha J M Wells (1997) Leaching and Runoff of Simazine, 2,4-D, and Bromide from Nursery Plots. Journal of Soil and Water Conservation. 52: 137-144.

33. Wilson RG, HH Cheng (1976) Breakdown and Movement of 2,4-D in the Soil Under Field Conditions. Weed Science 24(5): 461-466.

34. AW Hayes (2001) Principles and Methods of Toxicology ( $4^{\text {th }}$ Edn). Taylor and Francis, Philadelphia, PA, pp. 302.

35. Fent K (2003) Ecotoxicological problems associated with contaminated sites (review). Toxicol Lett 140(141): 353-365.

36. Fent K (2004) Ecotoxioclogical effects at contaminated sites. Toxicol 205: 223-240.

37. Lilienfeld, David E, M Gallo (1989) 2,4-D, 2,4,5-T, and 2,3,7,8-TCDD: An Overview. Epidemiologic Reviews 11: 19-58.

38. Van Vakenburg JW (1969) Pesticide Formulations Research: Physical and Colloidal Chemical Aspects; a symposium. American Chemical Society. Washington.

39. Reregistration Eligibility Decision (RED) 2,4-D; EPA 738-R-05-002 (2005) U.S. Environmental Protection Agency, Office of Prevention, Pesticides and Toxic Substances, Office of Pesticide Programs, U.S. Government Printing Office: Washington, DC.

40. Tomlin C D S (2006) The Pesticide Manual: A World Compendium (14 ${ }^{\text {th }}$ ed) British Crop Protection Council: Surrey, UK.

41. Herbicide Handbook (2002) Vencill WK (Ed), Weed Science Society of America: Lawrence ( $8^{\text {th }}$ ed), KS, pp 113-115.

42. WHO (1989) Environmental Health Criteria 84, Environmental Aspects - 2,4-Dichlorophenoxyacetic acid (2,4-D), International Programme on Chemical Safety, World Health Organization: Geneva, Switzerland.

43. Label Review Manual, US Environmental Protection Agency, Office of Prevention, Pesticides and Toxic Substances, Office of Pesticide

44. Peterson M E, Talcott P A (2006) Small Animal Toxicology ( $2^{\text {nd }}$ ed)Saunders Elsevier, St Louis, pp 734-735.

45. Campbell A, Chapman M (2000) Handbook of Poisoning in Dogs and Cats, Blackwell Science Ltd, Oxford, England, pp 220-221.

46. Arnold E K, Lovell R A, Beasley VR, Parker A J, Stedelin JR (1991) 2,4-D Toxicosis III: An Attempt to Produce 2,4-D Toxicosis in Dogs on Treated Grass Plots. Vet Hum Toxicol 33(5): 457-461.

47. Paulino C A, Guerra J L, Oliveira G H, Palmero Neto J (1996) Acute, Subchronic and Chronic 2,4-Dichlorophenoxyacetic Acid (2,4-D) Intoxication in Rats. Vet Hum Toxicol 38 (5): 348-352.

48. Reigart JR, Roberts J R (1999) Chlorophenoxy Herbicides. Recognition and Management of Pesticide Poisonings ( $5^{\text {th }}$ ed) US Environmental
Protection Agency, Office of Prevention, Pesticides and Toxic Substances, Office of Pesticide Programs, US Government Printing Office, Washington, DC.

49. Bradberry S M, Proudfoot A T, Vale J A (2004) Poisoning Due to Chlorophenoxy Herbicides. Toxicol 23(2): 65-73.

50. Charles J M, Cunny H C, Wilson R D, Bus J S (1996) Comparative Subchronic Studies on 2,4-Dichlorophenoxyacetic Acid, Amine, and Ester in Rats. Fundam Appl Toxicol 33: 161-165.

51. Charles J M, Bond D M, Jeffries T K, Yano B L, Stott W T, et al. (1996) Chronic Dietary Toxicity/ Oncogenicity Studies on 2,4-Dichlorphenoxyacetic Acid in Rodents. Fundam Appl Toxicol. 33: 166-172.

52. Charles J M, Dalgard D W, Cunny H C, Wilson R D, Bus J S (1996) Comparative Subchronic and Chronic Dietary Toxicity Studies on 2,4-Dichlorophenoxyacetic Acid, Amine, and Ester in the Dog. Fundam Appl Toxicol 29: 78-85.

53. Charles J M, Hanley TR, Wilson R D, Van Ravenzwaay B, Bus J S (2001) Developmental Toxicity Studies in Rats and Rabbits on 2,4-Dichlorophenoxyacetic Acid and its Forms. Toxicol Sci 60: 121-131.

54. Hoppin J A, Umbach D M, London S J, Alavanja M C R, Sandler D P (2002) Chemical Predictors of Wheeze among Farmer Pesticide Applicators in the Agricultural Health Study. Am J Respir Crit Care Med 165:683-689.

55. Kamel F, Tanner C M, Umbach D M, Hoppin J A, Alavanja M C R, et al. (2006) Pesticide Exposure and Self-reported Parkinson's Disease in the Agricultural Health Study. Am J Epidemiol 165 (4): 364-374.

56. Hayes H M, Tarone R E, Cantor K P, Jessen C R, McCurnin, et al. (1991) Case-Control Study of Canine Malignant Lymphoma: Positive Association with Dog Owner's Use of 2,4-Dichlorphenoxyacetic Acid Herbicides. J Natl Cancer Inst 83: 1226-1231.

57. Carlo G L, Cole P, MIller A B, Munro I C, Solomon K R, et al. (1992) Review of a Study Reporting an Association between 2,4-Dichlorophenoxyacetic Acid and Canine Malignant Lymphoma: Report of an Expert Panel. Regul Toxicol Pharmacol 16: 245-252.

58. Garabant D H, Philbert M A (2002) Review of 2,4-Dichlorophenoxyacetic Acid (2,4-D) Epidemiology and Toxicology. Crit. Rev Toxicol 32(4): 233-257.

59. Gandhi R, Wandji SA, Snedeker S (2000) Critical Evaluation of Cancer Risks from 2,4-D. Rev. Environ Contam Toxicol 167: 1-33.

60. Maire M A, Rast C, Landkocz Y, Vasseur P (2007) 2,4-Dichlorophenoxyacetic Acid: Effects on Syrian Hamster Embryo (SHE) Cell Transformation, c-Myc Expression, DNA Damage, and Apoptosis. Mutat Res 631: 124-136.

61. IARC (1987) Monographs on the Evaluation of Carcinogenicity Risks to Humans. Overall Evaluations of Carcinogencity: An Updating of IARC Monographs, International Agency for Research on Cancer: Lyon, France.

62. Madrigal Bujaidar E, Hernandez Ceruelos A, Chamorro G (2001) Induction of sister chromatid exchanges by 2,4-dichlorophenoxyacetic acid in somatic and germ cells of mice exposed in vivo. Food Chem Toxicol 39: 941-946.

63. Collins T F X, Williams C H (1971) Teratogenic Studies with 2,4,5-T and 2,4-D in the Hamster. Bull Environ Contam Toxicol 6(6): 559-567.

64. Lerda D, Rizzi R (1991) Study of reproductive function in persons occupationally exposed to 2,4-dichlorophenoxyacetic acid (2,4-D). Mutat Res 6(6): 47-50.

65. Relyea R A (2005) The Impact of Insecticides and Herbicides on the Biodiversity and Productivity of Aquatic Communities. Ecolol 15(2): 618-627. 
(C) This work is licensed under Creative BY DOI: 10.19080/OMCIJ.2019.09.555755
Your next submission with Juniper Publishers will reach you the below assets

- Quality Editorial service

- Swift Peer Review

- Reprints availability

- E-prints Service

- Manuscript Podcast for convenient understanding

- Global attainment for your research

- Manuscript accessibility in different formats

( Pdf, E-pub, Full Text, Audio)

- Unceasing customer service

Track the below URL for one-step submission

https://juniperpublishers.com/online-submission.php 